\title{
Trisomy 9p Syndrome in a Mentally Retarded Female Inherited from Maternal Reciprocal Translocation
}

\author{
Dhanlaxmi Shetty, K. Desai and Usha Dave \\ Centre for Research in Mental Retardation (CREMERE), Khushaldas Dagara House, \\ Malad (W), Mumbai-400 064, Maharashtra, India \\ E-mail: cremere@bom5.vsnl.net.in
}

KEYWORDS Trisomy 9 p; translocation (X; 9); maternal reciprocal translocation; mental retardation

\begin{abstract}
A rare case of trisomy 9 p syndrome resulting from maternal reciprocal translocation is reported here, in a 14-year old female child with mental and motor developmental delay. The characteristic phenotype features of this syndrome such as dysmorphic features, congenital anomalies, severe mental retardation and gross delay in speech were observed. The cytogenetic study showed 47,XX, +der (9), (9pter $\rightarrow 9 q 12 ; \mathrm{Xp} 22.2)$ mat. The mother was mentally normal, and her karyotype revealed chromosomal abnormality in terms of reciprocal translocation 46, XX, $\mathrm{t}(\mathrm{X} ; 9)(\mathrm{p} 22.2 \rightarrow$ ter; q13!ter), confirming her as a carrier and thus, leading to the inheritance of trisomy $9 \mathrm{p}$ in this girl child.
\end{abstract}

\section{INTRODUCTION}

Chromosomal breaks responsible for structural chromosomal abnormalities may occur spontaneously or as a result of mutant genes. Not all visually evident chromosomal aberrations confirm phenotypical abnormalities; and minor structural variation called polymorphism, occurs in $1-5 \%$ of the normal population. The major structural alterations are often associated with phenotypic abnormalities due to altered gene positioning. Chromosome 9 is important from the point of its structural aberrations involving different malformations, monosomy or partial trisomy, translocation as well as normal variants. The inversion 9 and $9 q h+$ are the commonly described variants in population, the latter due to varying amounts of heterochromatin near centromeric region. These normal variants are transmitted in dominant fashion. A complete trisomy of chromosome 9 is a rare disorder with most pateints dying before the age of 4 months (Canun et al. 1998). Trisomy $9 \mathrm{p}$ syndrome was first reported by Rethore et al. (1970) delineating pattern of malformation (congenital anomalies). We report here, a female child with mental retardation, facial dysmorphism, and other associated congenital defects having 9p trisomy.

Corressponding author: Dr. Usha P. Dave

Joint-Research Director-CREMERE

Centre for Research in Mental Retardation (CREMERE), Khushaldas Dagara House, Malad (W), Mumbai-400 064, Maharashtra, India

Telephone: $02228825300 / 02228810581$

Fax: 022 28810654, E-mail: cremere@bom5.vsnl.net.in

\section{CASE REPORT}

A proband, a 14 year old female was referred to a Clinical Genetic OPD of CREMERE. She was born prematurely ( 8 months), and was $4^{\text {th }}$ of a non-consanguineous couple. She came mainly with complaints of delayed mental, motor milestones and lack of speech. There was a history of mild birth asphyxia which was managed by resuscitation. She had short stature, crowded dysmorphic facial features and multiple congenital anomalies as given in Table no.1. She revealed severe mental retardation (IQ less than 35) when the standard battery of psychological tests were used.

At the time of her birth, mother's age was 31 years and father's age was 36 years; ruling out the advanced paternal or maternal age as one of the genetic predisposing factors. The pedigree revealed $1^{\text {st }}$ male sibling born premature ( 7 months) with normal delivery but died after 2 months of unknown cause. The other two female sibs are mentally normal having normal children.

Dysmorphism and Congenital Anomalies: On clinical examination, the index case (Fig.1a) showed multiple congenital anomalies and several dysmorphic features (Table no.1). The congenital hand anomalies involving bones are well depicted in Figure 1b. The multiple organs such as eye, head, hand, feet, spine, neck, muscle, and thorax were involved (Arnold et al.1995); the details of the findings are given in Table no.1. The X-ray confirmed delayed skeletal maturation. She had convulsions since birth, but the fre- 


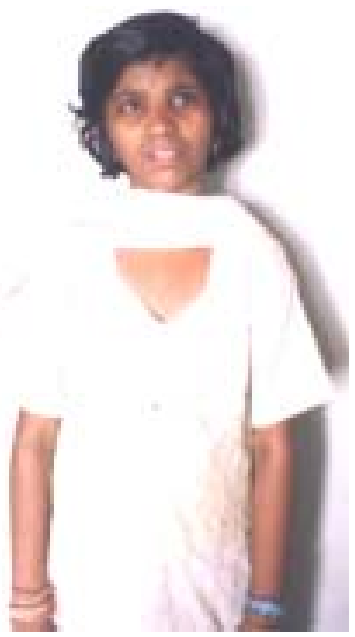

Fig.1a

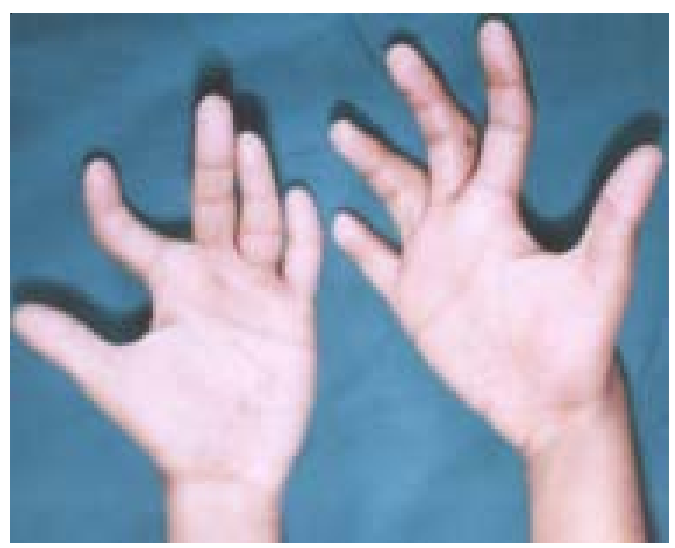

Fig.1b
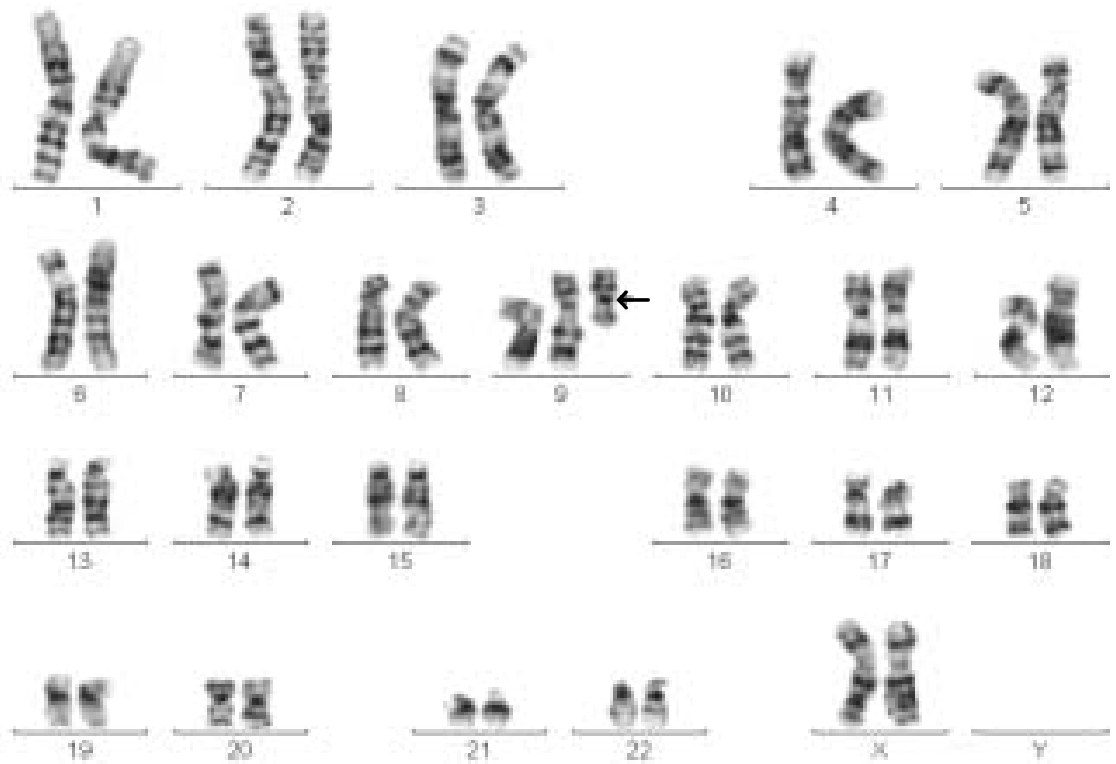

Fig.1c

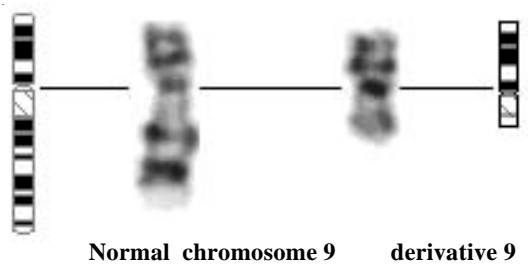

Fig.1d

Fig.1. (a) Proband, (b) congenital hand anomalies, (c) karyotype showing trisomy 9p (arrow), (d) showing normal 9chromosome on the left and derivative chromosome 9 on the right 
quency is now less, and is not on any anticonvulsant medication for the present occasional seizures.

The mother appeared to be phenotypically normal with no mental retardation (Fig. 2a)

Cytogenetic Method: $2 \mathrm{ml}$ of intravenous blood was collected from both the proband and her mother, (as father is not alive) asceptically in a sodium heparin precoated syringe. Phytohemaglutinin stimulated lymphocyte cultures were set up and harvested, the slides were prepared according to the standard method (Moorehead et al. 1960) and were stained using Giemsa, (Hungerford 1965 and Seabright 1971). The separate lymphocyte cultures were also set up for High Resolution Banding using Ethidium bromide method, which shows more chromosomal bands (about 400-600), in comparision with the routine G-Banding Method (about 250-300).

It helps in studying structural variations better than G- banding, especially in the absence of FISH facilities. Metaphases were studied under oil imersion lens $(100 \mathrm{X})$ in Zeiss microscope and were captured using KaryoImager Version V 1.0. For each sample, 100 metaphases were screened for chromosomal anomalies, which were designated according to the standard nomenclature (ISCN 1995).

\section{RESULTS}

The cytogenetic analysis of both GTG and high resolution banding metaphases was conducted. The karyotype revealed 47,XX, +der (9)(9pter $\rightarrow 9 q 12)$ mat (Fig. 1c) leading to partial trisomy of 9p, which is explained in Figure 1d.The mother of the proband showed reciprocal translocation, 46,X, t $(\mathrm{X} ; 9)(\mathrm{p} 22.2 \rightarrow$ ter::q13 $\rightarrow$ ter $)$ (Fig. 2d). The part of $q$ arm of chromosome 9 is transferred to terminal region of $\mathrm{p}$ arm of $\mathrm{X}$ chromosome, which is schematically shown in Figures $2 \mathrm{~b}$ and $2 \mathrm{c}$. The more and clear chromosome bands observed by high resolution banding technique, helped in detecting clear cut trisomy $9 \mathrm{p}$ in the proband.

\section{DISCUSSION}

Knowledge of the critical regions in the chromosomes is very useful in correlating the genotype-phenotype and defining a particular genetic syndrome. High resolution banding
Table 1: Clinical findings and dysmorphic features

\begin{tabular}{|c|c|}
\hline Organ & Abnormal phenotypes \\
\hline Head and Neck & $\begin{array}{l}\text { Microcepaly, crowded } \\
\text { features }\end{array}$ \\
\hline Ears; eyes; nose & $\begin{array}{l}\text { Large and low-set ears, } \\
\text { deep-set, acentric } \\
\text { displacement of pupils, } \\
\text { hypertelorism, } \\
\text { enopthalmos, down } \\
\text { slanting palpebral fisures; } \\
\text { Prominent, broad root and } \\
\text { bridge of nose }\end{array}$ \\
\hline Mouth and oral structures & $\begin{array}{l}\text { High-arched palate, down } \\
\text { curved corners of mouth }\end{array}$ \\
\hline Hand and Foot & $\begin{array}{l}\text { Small hands and feet, } \\
\text { clinodactyly of little } \\
\text { fingers, hypoplasia of } \\
\text { phalanges, single palmar } \\
\text { crease on both palms }\end{array}$ \\
\hline Extremities & Joint hyper extensibility \\
\hline Spine & Lordosis and scoliosis \\
\hline Muscles & Hypotonia \\
\hline Neck; Thorax & $\begin{array}{l}\text { Short neck; funnel chest, } \\
\text { protruding tummy }\end{array}$ \\
\hline Bones and Joints & $\begin{array}{l}\text { Delayed skeletal } \\
\text { maturation }\end{array}$ \\
\hline Growth and development & $\begin{array}{l}\text { Growth and motor retar- } \\
\text { dation; delayed puberty }\end{array}$ \\
\hline Performance & $\begin{array}{l}\text { Severe mental retardation, } \\
\text { language tends to be most } \\
\text { significantly delayed }\end{array}$ \\
\hline Nervous system & Seizures \\
\hline Behaviour & Reluctant, fear \\
\hline
\end{tabular}

technique depicts these critical regions clearly, and thus helps in detecting structural chromosomal aberrations. The various congenital malformations observed can then be correlated with such chromosomal anomaly. In this report, a rare case of partial trisomy $9 p(9 p t e r \rightarrow 9 q 12)$ was noticed in the proband. This extra chromosome 9 $\mathrm{p}$ was inherited from the mother who had balanced reciprocal translocation between chromosome $\mathrm{X}$ and 9. During the meiotic division the abnormal chromosomal segregation occurred leading to the trisomy $9 \mathrm{p}$ in the proband.

The partial trisomy 9pter $\rightarrow \mathrm{q} 11-13$ is associated not only with the typical craniofacial features but also skeletal and cardiac defects (Centerwall et al. 1975), which was observed in the present case. Mental retardation, short stature, peculiar face and minor defects have been reported by Canun et al. (1998) in a female 46,X, der (9) t (X; 9) but she showed combined trisomy (9q12:q32) and Ullrich-Turner syndrome. In some cases, trisomy $9 \mathrm{p}$ syndrome is reported to be involved with Dandy- Walker phenotype malformation (Hannan 


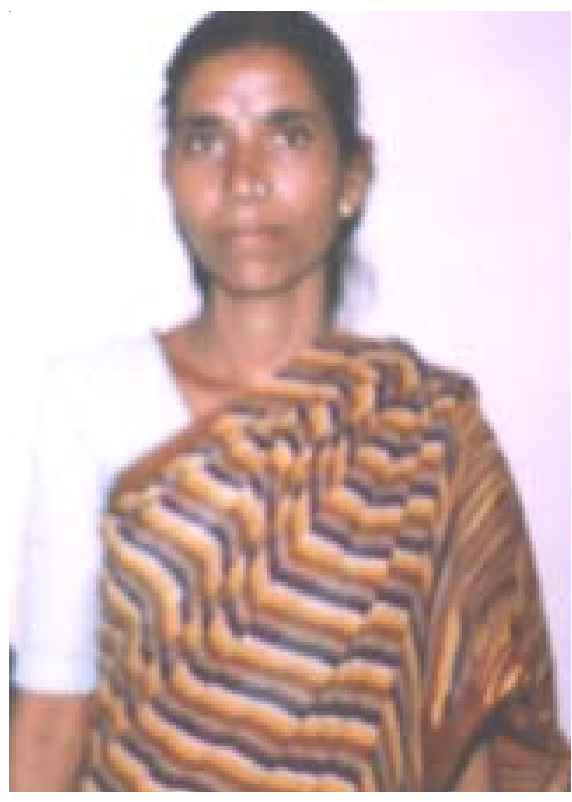

Fig.2a

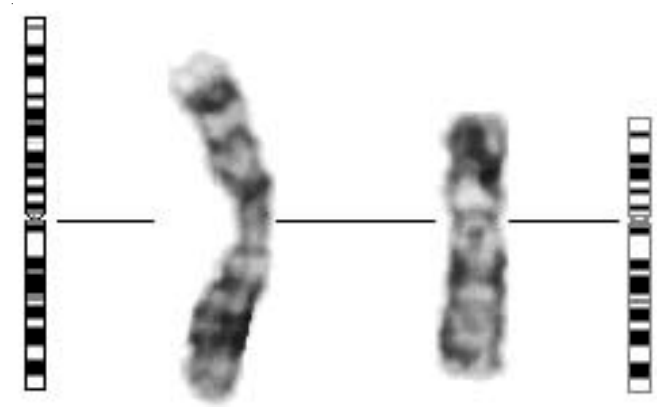

Fig.2b

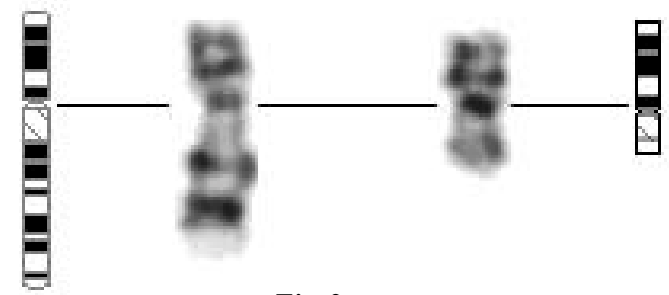

Fig.2c
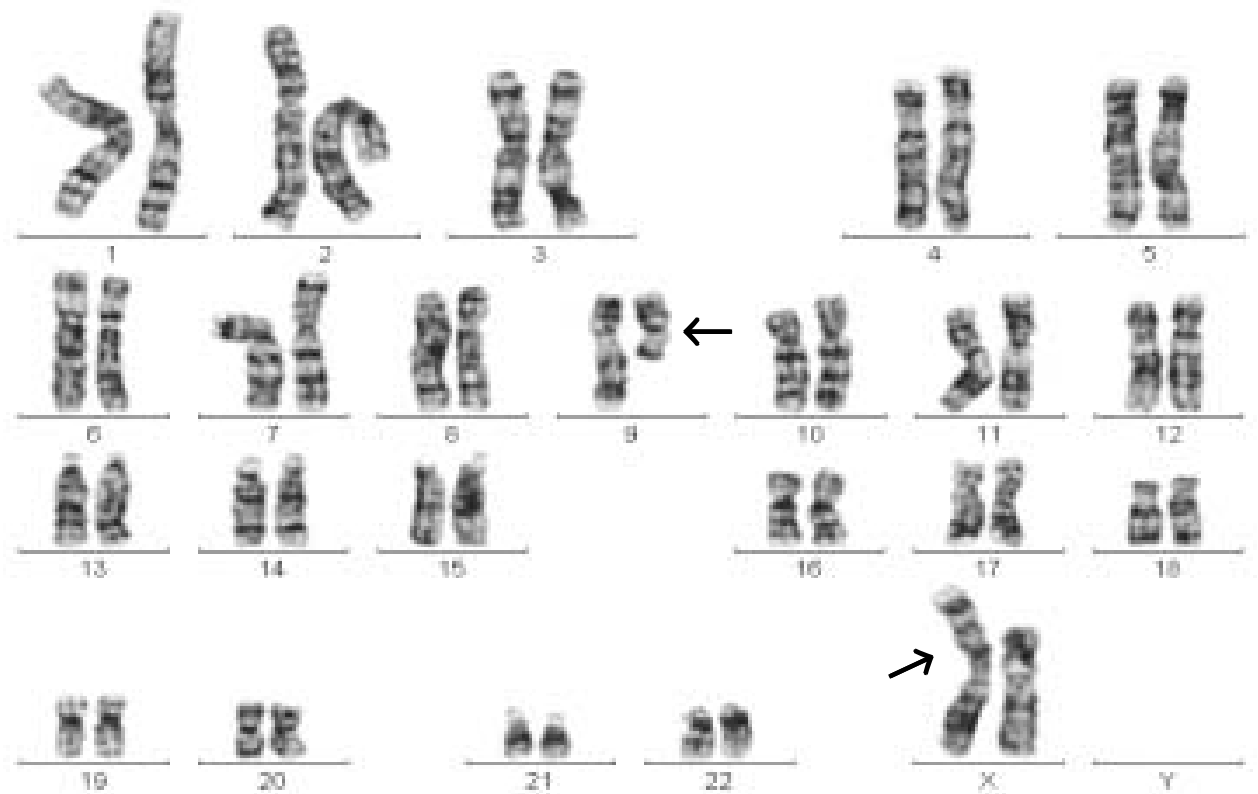

Fig.2d

Fig. 2. (a) Mother of proband, (b) showing derivative $X$ chromosome on the left and normal chromosome $X$ on the right (c) showing normal 9 chromosome on the left and derivative chromosome 9 on the right (d) karyotype showing translocation between chromosome $X$ and chromosome 9 (arrows) 
et al. 1999; Bureau et al. 1993). A 19-week stillborn female fetus with bilateral cleft palate, horseshoe kidney, low set ears and IUGR was found to have a supernumerary derivative chromosome 9 der (9) \} with an apparent tandem duplication in long arm (Wyandt et al. 1984). Low frontal hairline, circular placement of hair around face and scarse inverted eyebrows were new clinical findings reported in two brothers having 9p trisomy syndrome by Hacihanefioglu et al. (2002). Effect of balanced X/ autosome translocation on sexual and physical development has been discussed in four female pateints (Kleezkowska et al.1985).

Regarding clinical aspects of our case, it showed similar findings as that of trisomy $9 p$ syndrome (Rethore et al. 1970; Castorina et al. 2000; Littooij et al. 2002). However, the crowded facial features, seizures, delayed puberty, gross delay in speech and behavioural abnormality were the additional findings in the present case. In the cases published so far, the breakpoints as well as the chromosomal segments involved in the $t(X ; 9)$ were different from the present case. A child with a supernumerary chromosome inherited from the maternal balanced translocation, similar to that found in our case and leading to pure trisomy $9 \mathrm{p}$ is described by Tihy et al. (2000).

A clear-cut break points could be depicted in the present study due to high resolution banding technique. Further, molecular studies using FISH are useful to ascertain the DNA involvment. The trisomy 9p observed in the proband case is due to the most probable mode of unbalance at birth. It is also supporting the fact that there is a higher risk of multiple congenital anomalies and mental retardation resulting from reciprocal carriers giving birth to unbalanced live-born. Since, there was no loss or gain of genetic material in the mother, she appeared to be phenotypically normal. However, in the proband, trisomy $9 p$ resulted in severe mental retardation with multiple congenital anomalies.

The positoning of the genes responsible for human malformations could be obtained from the studies of phenotypic effects of human chromosomal aberrations. We conclude that the correlative findings of clinical and cytogenetic analysis could be used in the diagnosis of $9 p$ trisomy syndrome along with the other welldocumented characteristics. The critical break points were detected due to high-resolution banding technique used. This is significant from the point of genetic counselling to the pateint and family members while offering the recurrent risk with a preventive approach.

\section{REFERENCES}

Arnold GL, Kirby RS, Stern TP, Sawyer JR 1995. Trisomy 9: review and report of two cases. American Journal of Medical Genetics, 56: 252-257.

Canun S, Mutchinick O, Shaffer LG, Fernandez C, 1998. Combined trisomy 9 and Ullrich-Turner syndrome in a girl with a 46,X, der (9) t $(X ; 9)(\mathrm{q} 12 ; \mathrm{q} 32)$ karyotype. Am J Med Genet, 80(3): 199-203.

Castorina P, Rodeschini O, Nocera G, Larizza L 2000. Reproductive follow-up of carriers of familial reciprocal balanced translocations involving chromosome 9 and comparison with predicted outcome. Genet Couns, 11(3): 229-239.

Centerwall, WR, and Beatty- de Sana, JW, 1975 .The trisomy 9p syndrome. Pediatrics, 56: 748.

Hacihanefiogglu S, Guven GS, Deviven A, Silahtaroglu AN, Yosunvkaya Fenerci E, Ozkili CA, Yuksei A 2002. Trisomy 9p syndrome in two brothers with new clinical findings and review of the literature. Genet Couns, 13(1): 41-48.

Hannam S, Greenough A, Dawson JM 1999. An unusual presentation of trisomy $9 \mathrm{p}$ syndrome with a partial Dandy-walker malformation. Eur J Pediatr, 158(2): 1012 .

Hungerford DA, 1965. Leucocytes cultured from small inocula of whole blood and preparation of metaphase chromosomes by treatment with hypotonic KCL. Stain Tecnology, 40: 333.

ISCN 1995. An International System for Human Cytogenetic Nomenclature. F Mitelman (Ed.). Basal: S Karger.

Kenneth Lyons Jones 1997. Duplication 9p syndrome. In: Smith's Recognizable Patterns of Human Malformation, ( $\left.5^{\text {th }} E d\right)$. W.B. Sauders Company, Ch 1, pp.50-53.

Kleezkowska A, Fryns JP, Vinken L, vanden Berghe $\mathrm{H}$ 1985. Effect of balanced X/ autosome translocations on sexual and physical development.A personal experience in 4 pateints. Clin Genet, 27(2): 147-152.

Littooij AS, Hochstenbach R, Sinke RJ, Van Tintelen P, Giltay JC, 2002. Two cases with partial trisomy 9p: molecular cytogenetic characterization and clinical follow-up. Am J Med Genet, 109(2): 125132.

Moorehead PS, Nowell PS, Mellman WJ, Battups DM, Hungerford DA, 1965. Chromosomal preparation of luecocytes cultured from human peripheral blood. Exp Cell Res, 20: 613- 616.

Rethore, MO, et al 1970. Surquate cas de trisomie pour le bras court du chromosome 9, Individualsation d'une nouvelle entite morbide. Ann Genet, 13: 217.

Seabright M 1971. A rapid banding technique for human chromosome. Lancet, 2: 971-972.

Tihy F, Lemyre E, Dallaire L, Lemieux N, 2000. Supernumerary chromosome inherited from maternal balanced translocation leading to pure trisomy 9p. Am J Med Genet, 91(5): 383-386.

Wyandt HE, Lebo RV, Fenerci EY, Sadhu DN, Milunsky JM 2002.Tandem duplication/deletion in a maternally derived chromosome 9 supernumerary derivative resulting in $9 \mathrm{p}$ trisomy and partial $9 \mathrm{q}$ tetrasomy. Am J Med Genet, 93(4): 305-312. 